\title{
Analisis Faktor Determinan Permasalahan Pelayanan Kesehatan Ibu dan Anak
}

\section{Determinant Factor Analysis on Mother and Child Health Service Problem}

\author{
Zahtamal, Tuti Restuastuti, Fifia Chandra
}

Bagian Ilmu Kesehatan Masyarakat Kedokteran Komunitas Fakultas Kedokteran Universitas Riau

\begin{abstract}
Abstrak
Masalah kesehatan yang dihadapi Indonesia kini adalah status kesehatan masyarakat yang rendah, antara lain ditandai dengan angka kematian ibu dan bayi yang tinggi serta masih banyak indikator pelayanan kesehatan ibu dan anak (KIA) yang belum ideal. Penelitian ini bertujuan untuk mengetahui faktor-faktor yang berhubungan dengan permasalahan pelayanan KIA. Desain penelitian yang digunakan pada penelitian ini adalah cross sectional, data faktor predisposisi dikumpulkan dari 550 orang responden yang tersebar di 4 kabupaten/kota dengan menggunakan kuesioner. Selanjutnya, data faktor determinan yang lain dikumpulkan dengan wawancara pada informan antara lain kepala dinas kesehatan kabupaten/kota dan kepala subdinas kesehatan keluarga. Hasil penelitian menunjukkan faktor predisposisi yang berhubungan dengan pelayanan KIA yaitu sikap responden, pengaruh orang yang memutuskan pemilihan pelayanan kesehatan dalam keluarga, serta pengetahuan responden terkait pelayanan KIA. Diketahui juga bahwa masih banyak kepercayaan masyarakat terkait aspek KIA yang belum sesuai dengan nilai-nilai kesehatan. Faktor pemungkin yang berhubungan dengan pelayanan KIA antara lain distribusi tenaga kesehatan masih belum merata, kualitas ketenagaan pemberi pelayanan KIA belum ideal, dan sarana pendukung pelayanan belum memadai. Faktor pendorong yang berhubungan dengan pelayanan KIA antara lain belum ada kebijakan daerah sebagai acuan, dana pendukung pelayanan belum memadai serta kuantitas kegiatan yang seharusnya dilakukan secara lintas sektoral masih banyak yang belum terealisasi dan belum optimal.

Kata kunci: Kesehatan ibu dan anak, permasalahan pelayanan, pelayanan kesehatan
\end{abstract}

\section{Abstract}

The current issue of health in Indonesia is the low status of public health, among others, characterized by high rates of maternal and infant mortality and many indicators of maternal and child health $(\mathrm{MCH})$ services that have not been ideal yet. This study aims to determine the factors associated with problems of $\mathrm{MCH}$ services. This design used in this research is cross sectional. Predisposing factor data were collected from 550 respondents who were scattered in four districts using a questionnaire. Furthermore, another determinant factor data were collected by interviewing the informants, among others, chief of district health department, Head of Sub Office of Family Health. The results showed that the predisposing factors associated with $\mathrm{MCH}$ services is the attitude of the respondent, the influence of people who make decisions in family health care, respondents' knowledge related to $\mathrm{MCH}$ services. Please also note that there are still many aspects of $\mathrm{MCH}$ related public trust that has not been in accordance with the values of health. Enabling factors associated with $\mathrm{MCH}$ services including the distribution of health workers is still not equitable, quality of $\mathrm{MCH}$ service workforce has not been ideal and service support facilities have been inadequate. Reinforcing factors associated with $\mathrm{MCH}$ services, among others, the lack of regional policy as a benchmark, the fund has not been adequate support services, the quantity of activities that should be done across sectors is still much that has not been realized and is still not optimal.

Key words: Mother and child health, service problem, health care

\section{Pendahuluan}

Masalah kesehatan di Indonesia saat ini adalah status kesehatan masyarakat yang masih rendah, antara lain ditandai dengan angka kematian ibu (AKI) dan angka kematian bayi (AKB) yang tinggi. Berdasarkan Survei Kesehatan Dasar tahun 2007, AKI di Indonesia masih berada pada angka 228 per 100.000 kelahiran hidup. Demikian pula AKB, masih berada pada kisaran 26,9 per 1.000 kelahiran hidup. Tahun 2004, target

Alamat Korespondensi: Zahtamal, Bagian Ilmu Kesehatan Masyarakat Kedokteran Komunitas Fakultas Kedokteran Universitas Riau, Jl. Diponegoro No.1Pekanbaru,Hp.081371530203,e-mail:ta_mal75@yahoo.co.id 
Departemen Kesehatan Republik Indonesia yang diharapkan dapat dicapai pada tahun 2010 adalah AKI menjadi 125 per 100.000 kelahiran hidup dan AKB menjadi 15 per 1.000 kelahiran hidup. ${ }^{1}$ Berdasarkan data Dinas Kesehatan Provinsi Riau, diketahui AKB yaitu 26 per 1.000 kelahiran hidup dan angka kematian anak balita yaitu 60 per 1.000 kelahiran hidup. Tahun 2006, jumlah kematian bayi mencapai 1.272 kasus, sedangkan jumlah kematian ibu maternal mencapai 179 kasus. $^{2}$

Program kesehatan ibu dan anak (KIA) untuk mengurangi AKI dan AKB telah banyak dilakukan. Program tersebut antara lain Safe Motherhood. Program ini di Indonesia dituangkan dalam bentuk program Keluarga Berencana $(\mathrm{KB})$, pelayanan pemeriksaan dan perawatan kehamilan, persalinan sehat dan aman, serta pelayanan obstetri esensial di pusat layanan kesehatan masyarakat. Masih tingginya AKI dan AKB di Indonesia termasuk Provinsi Riau disebabkan oleh berbagai faktor, antara lain dari faktor predisposing, faktor pemungkin (enabling) serta faktor pendorong atau penguat (reinforcing). Faktor-faktor tersebut berupa berbagai hambatan, antara lain dari aspek geografis, ekonomi, sosiokultural, yang diperberat oleh kelemahan dalam mendeteksi, memutuskan tindakan, merujuk dan keterlambatan dalam menangani keluarga sakit/bermasalah setelah sampai di tempat pelayanan kesehatan komperehensif. Kenyataanya, belum banyak informasi yang menggambarkan bagaimana situasi faktor-faktor tersebut, terutama aspek perilaku masyarakat. Padahal, strategi dan kebijakan yang tepat dengan berdasarkan informasi/bukti sangat diperlukan dalam rangka mengatasi persoalan KIA yang belum optimal. Tujuan yang ingin dicapai dalam penelitian ini adalah diperolehnya faktorfaktor yang berhubungan dengan pelayanan KIA.

\section{Metode}

Jenis penelitian yang digunakan adalah cross sectional yakni meneliti faktor determinan dan faktor dominan masalah KIA di masyarakat. Waktu penelitian dilakukan pada tahun 2010. Jumlah wilayah studi responden ditentukan secara quota sampling. Besar sampel dalam kajian ini sebanyak 550 orang masyarakat (setiap kabupaten/kota sekitar 120-150 orang). Selanjutnya, data faktor penentu lainnya secara kualitatif dikumpulkan dengan wawancara pada informan, antara lain kepala dinas kesehatan kabupaten/kota dan kepala sub dinas kesehatan keluarga. Instrumen yang digunakan adalah format identifikasi indikator pelayanan kesehatan dari data sekunder dan kuesioner/panduan wawancara. Pengelolaan data yang didapat dilakukan untuk data kualitatif dan kuantitatif. Pengelolaan secara statistik/ kuantitatif berupa uji chi square dan perhitungan prevalensi rasio (PR) dengan tingkat kemaknaan hubungan $\mathrm{p}<0,05$. Pengolahan dan analisis data hasil penelitian dengan menggunakan bantuan peranti lunak komputer.

\section{Hasil}

Faktor-faktor yang Berhubungan dengan Praktik Kehamilan, Persalinan, dan Nifas Ibu (Maternal)

Beberapa variabel secara statistik berhubungan bermakna dengan praktik responden terkait kesehatan maternal. Variabel tersebut adalah cara pembayaran kesehatan, aksesabilitas terhadap fasilitas kesehatan, pengaruh orang yang memutuskan dalam upaya pencarian pelayanan kesehatan, pengetahuan responden tentang kesehatan ibu, serta sikap ibu terhadap pelayanan kesehatan maternal. Berdasarkan analisis bivariat, variabel sikap merupakan variabel dengan nilai PR terbesar, praktik responden yang buruk terkait pelayanan kesehatan maternal 6 kali lebih banyak pada ibu dengan sikap yang negatif daripada yang positif. Sedangkan variabel usia pernikahan, jumlah anak, pendapatan keluarga serta tenaga yang memberikan pelayanan tidak berhubungan dengan praktik responden terkait pelayanan kesehatan maternal (Lihat Tabel $1)$.

Analisis multivariat dilakukan untuk mengetahui pengaruh secara bersama variabel bebas terhadap variabel terikat dengan menggunakan uji regresi logistik ganda. Variabel bebas yang mempunyai $\mathrm{p}<0,25$ pada analisis bivariat dijadikan sebagai variabel kandidat dalam uji regresi logistik ganda. Variabel kandidat yang dimasukkan dalam analisis multivariat adalah jumlah anak, tenaga penolong pelayanan kesehatan keluarga, cara pembayaran kesehatan, aksesabilitas terhadap fasilitas kesehatan, orang yang memutuskan dalam pelayanan kesehatan, serta pengetahuan dan sikap responden.

Hasil analisis multivariat menunjukkan 4 variabel bebas berpengaruh kuat terhadap praktik responden terkait kesehatan maternal. Variabel tersebut meliputi sikap responden (adjusted $\mathrm{PR}=8,39 ; \mathrm{p}=0,000 ; 95 \% \mathrm{CI}$ $=4,913-14,332)$, aksesabilitas terhadap pelayanan kesehatan (adjusted $\mathrm{PR}=3,171 ; \mathrm{p}=0,023 ; 95 \% \mathrm{CI}=$ 1,175-8,558), orang yang memutuskan pemilihan pelayanan kesehatan dalam keluarga (adjusted $\mathrm{PR}=$ $2,614 ; \mathrm{p}=0,018 ; 95 \% \mathrm{CI}=1,183-5,778)$, dan pengetahuan responden (adjusted $\mathrm{PR}=1,670 ; \mathrm{p}=$ $0,042 ; 95 \%$ CI $=1,019-2,738)$. Secara bersamaan, diketahui bahwa sikap merupakan variabel yang berpengaruh kuat terhadap praktik responden, dimana praktik yang buruk terkait pelayanan kesehatan maternal 8 kali lebih banyak pada responden yang memiliki sikap negatif daripada yang memiliki sikap positif.

Berdasarkan analisis multivariat diperoleh hasil bahwa probabilitas seseorang akan berpraktik buruk terhadap pelayanan kesehatan maternal jika memiliki 
Tabel 1. Faktor-faktor yang Mempengaruhi Praktik Kesehatan Maternal

\begin{tabular}{|c|c|c|c|c|c|c|c|}
\hline \multirow{2}{*}{ Variabel } & \multirow{2}{*}{ Kategori } & \multicolumn{2}{|c|}{ Praktik terkait Kesehatan Maternal } & \multirow{2}{*}{$\mathbf{n}$} & \multirow{2}{*}{$\mathrm{X}^{2}$} & \multirow{2}{*}{ Nilai p } & \multirow{2}{*}{ PR (CI 95\%) } \\
\hline & & Buruk & Baik & & & & \\
\hline \multirow[t]{2}{*}{ Usia pernikahan } & $\leq 20$ tahun & $23(17,4 \%)$ & 109 & 132 & 0,82 & 0,365 & 0,828 \\
\hline & $>20$ tahun & $88(21,1 \%)$ & 330 & 418 & & & $(0,54-1,25)$ \\
\hline \multirow[t]{2}{*}{ Jumlah anak } & $>3$ orang & $21(26,6 \%)$ & 58 & 79 & 2,34 & 0,126 & 1,391 \\
\hline & $1-3$ orang & $90(19,1 \%)$ & 381 & 471 & & & $(0,92-2,09)$ \\
\hline \multirow[t]{2}{*}{ Pendapatan } & $\leq 2.000 .000$ & $92(19,8 \%)$ & 372 & 464 & 0,231 & 0,631 & 0,897 \\
\hline & 2.000 .000 & $19(22,1 \%)$ & 67 & 86 & & & $(0,58-1,39)$ \\
\hline \multirow[t]{2}{*}{ Tenaga pelayanan kesehatan } & Nonkesehatan & $3(37,5 \%)$ & 5 & 8 & 1,511 & 0,206 & 1,882 \\
\hline & Kesehatan & $108(19,9 \%)$ & 434 & 542 & & & $(0,76-4,68)$ \\
\hline \multirow{2}{*}{ Cara bayar } & Sendiri & $70(17,6 \%)$ & 327 & 397 & 5,76 & 0,016 & 0,658 \\
\hline & Asuransi kesehatan & $41(26,8 \%)$ & 112 & 153 & & & $(0,47-0,92)$ \\
\hline \multirow[t]{2}{*}{ Akses pelayanan kesehatan } & Sulit & $12(48,0 \%)$ & 13 & 25 & 12,58 & 0,000 & 2,545 \\
\hline & Mudah & $99(18,9 \%)$ & 426 & 525 & & & $(1,63-3,97)$ \\
\hline \multirow[t]{2}{*}{ Otoritas pelayanan kesehatan } & Keluarga & $17(45,9 \%)$ & 20 & 37 & 16,35 & 0,000 & 2,51 \\
\hline & Suami-istri & $94(18,3 \%)$ & 419 & 513 & & & $(1,69-3,72)$ \\
\hline \multirow[t]{2}{*}{ Pengetahuan } & Kurang & $58(31,5 \%)$ & 126 & 184 & 22,07 & 0,000 & 2,18 \\
\hline & Baik & $53(14,5 \%)$ & 313 & 366 & & & $(1,57-3,02)$ \\
\hline \multirow[t]{2}{*}{ Sikap } & Negatif & $90(40,2 \%)$ & 134 & 224 & 93,81 & 0,000 & 6,28 \\
\hline & Netral positif & $21(6,4 \%)$ & 305 & 326 & & & $(4,00-9,72)$ \\
\hline
\end{tabular}

sikap negatif, aksesabilitas pelayanan kesehatan sulit, pengambil keputusan dalam menentukan pelayanan kesehatan adalah suami-istri dan melibatkan orang lain/keluarga serta berpengetahuan buruk yaitu 90\%.

\section{Faktor-faktor yang Berhubungan dengan Praktik Kesehatan Bayi dan Anak}

Beberapa variabel secara statistik berhubungan bermakna dengan praktik responden terkait kesehatan bayi dan anak. Variabel tersebut adalah usia pernikahan, jumlah anak, pendapatan keluarga, cara pembayaran kesehatan, aksesabilitas terhadap fasilitas kesehatan, pengaruh orang yang memutuskan dalam upaya pencarian pelayanan kesehatan, pengetahuan serta sikap responden terhadap pelayanan kesehatan untuk bayi dan anak. Berdasarkan analisis bivariat, variabel pengaruh orang yang memutuskan dalam upaya pencarian pelayanan kesehatan dan pengetahuan responden tentang kesehatan bayi dan anak merupakan variabel dengan nilai PR terbesar. Berdasarkan hasil ini diketahui bahwa praktik responden yang buruk terkait pelayanan kesehatan bayi dan anak sama yaitu 5 kali lebih banyak pada responden dengan pola pengambilan keputusan dalam memilih/memutuskan pelayanan kesehatan adalah suami-istri dan melibatkan orang lain/keluarga serta berpengetahuan buruk (Lihat Tabel 2).

Hasil analisis multivariat menunjukkan hanya 4 variabel bebas yang mempunyai pengaruh kuat terhadap praktik responden terkait kesehatan bayi dan anak. Variabel tersebut yaitu orang yang memutuskan pemilihan pelayanan kesehatan dalam keluarga (adjusted
$P R=5,992 ; p=0,000 ; 95 \% C I=2,525-14,218)$, pengetahuan responden (adjusted $\mathrm{PR}=5,449 ; \mathrm{p}=0,000$; 95\% CI $=2,318-12,805$ ), sikap responden (adjusted $\mathrm{PR}$ $=4,884 ; \mathrm{p}=0,000 ; 95 \% \mathrm{CI}=2,318-12,805)$, dan cara pembayaran (adjusted $\mathrm{PR}=4,494 ; \mathrm{p}=0,001 ; 95 \% \mathrm{CI}=$ 1,838-10,993). Secara bersamaan, pengaruh orang yang memutuskan pemilihan pelayanan kesehatan dalam keluarga merupakan variabel yang berpengaruh kuat terhadap praktik responden, dimana praktik yang buruk terkait pelayanan kesehatan bayi dan anak 6 kali lebih banyak pada responden yang pengambilan keputusannya suami-istri dan melibatkan orang lain/keluarga.

Berdasarkan analisis multivariat ini diperoleh hasil bahwa probabilitas seseorang akan memiliki praktik yang buruk terhadap pelayanan kesehatan bayi dan anak jika memiliki sikap yang negatif, pengambil keputusan dalam menentukan pelayanan kesehatan adalah oleh suami-istri dan melibatkan orang lain/keluarga, berpengetahuan buruk serta pola pembayaran pelayanan kesehatan keluarga secara langsung/out of pocket adalah $87 \%$.

\section{Hubungan Faktor Sosiokultural dengan Praktik Masyarakat terkait Pelayanan Kesehatan Ibu dan Anak}

Masih banyak kepercayaan masyarakat yang belum sesuai dengan nilai-nilai kesehatan, terutama terhadap aspek KIA. Sebanyak 274 orang yang menjawab pernyataan kebiasaan/tradisi yang diterapkan/dipercayai dalam keseharian responden yang berhubungan dengan kesehatan maternal didapatkan data bahwa ada 124 $(45,26 \%)$ yang memiliki kepercayaan yang tidak sesuai dengan nilai-nilai kesehatan. Kepercayaan yang tidak 
Tabel 2. Hubungan Faktor Penentu yang Mempengaruhi Praktik terkait Kesehatan Bayi dan Anak

\begin{tabular}{|c|c|c|c|c|c|c|c|}
\hline \multirow{2}{*}{ Variabel } & \multirow{2}{*}{ Kategori } & \multicolumn{2}{|c|}{ Praktik terkait Kesehatan Maternal } & \multirow{2}{*}{$\mathbf{n}$} & \multirow{2}{*}{$\mathrm{X}^{2}$} & \multirow{2}{*}{ Nilai $p$} & \multirow{2}{*}{ PR (CI 95\%) } \\
\hline & & Buruk & Baik & & & & \\
\hline \multirow[t]{2}{*}{ Usia pernikahan } & $\leq 20$ tahun & $23(17,4 \%)$ & 109 & 132 & \multirow[t]{2}{*}{5,66} & \multirow[t]{2}{*}{0,017} & 1,78 \\
\hline & $>20$ tahun & $41(9,8 \%)$ & 337 & 418 & & & $(1,11-2,85)$ \\
\hline \multirow[t]{2}{*}{ Jumlah anak } & $>3$ orang & $16(20,3 \%)$ & 63 & 79 & \multirow[t]{2}{*}{6,66} & \multirow[t]{2}{*}{0,010} & 1,987 \\
\hline & $1-3$ orang & $48(10,2 \%)$ & 423 & 471 & & & $(1,19-3,32)$ \\
\hline \multirow{2}{*}{ Pendapatan } & $\leq 2.000 .000$ & $43(9,3 \%)$ & 421 & 464 & \multirow{2}{*}{16,19} & \multirow{2}{*}{0,000} & 0,38 \\
\hline & 2.000 .000 & $21(24,4 \%)$ & 65 & 86 & & & $(0,24-0,61)$ \\
\hline \multirow[t]{2}{*}{ Tenaga pelayanan kesehatan } & Nonkesehatan & $2(25,0 \%)$ & 6 & 8 & \multirow[t]{2}{*}{1,41} & \multirow[t]{2}{*}{0,235} & 2,19 \\
\hline & Kesehatan & $62(11,4 \%)$ & 480 & 542 & & & $(0,64-7,42)$ \\
\hline \multirow[t]{2}{*}{ Cara bayar } & Sendiri & $57(14,4 \%)$ & 340 & 397 & \multirow[t]{2}{*}{10,28} & \multirow[t]{2}{*}{0,001} & 3,14 \\
\hline & Asuransi kesehatan & $7(4,6 \%)$ & 146 & 153 & & & $(1,4-6,72)$ \\
\hline \multirow[t]{2}{*}{ Akses pelayanan kesehatan } & Sulit & $9(36,0 \%)$ & 16 & 25 & \multirow[t]{2}{*}{15,20} & \multirow[t]{2}{*}{0,000} & 3,44 \\
\hline & Mudah & $55(10,5 \%)$ & 470 & 525 & & & $(1,93-6,13)$ \\
\hline \multirow[t]{2}{*}{ Otoritas pelayanan kesehatan } & Keluarga & $18(48,6 \%)$ & 19 & 37 & \multirow[t]{2}{*}{52,85} & \multirow[t]{2}{*}{0,000} & 5,42 \\
\hline & Suami-istri & $46(9,0 \%)$ & 467 & 513 & & & $(3,53-8,35)$ \\
\hline \multirow[t]{2}{*}{ Pengetahuan } & Kurang & $56(18,1 \%)$ & 254 & 310 & \multirow{2}{*}{28,55} & \multirow[t]{2}{*}{0,000} & 5,42 \\
\hline & Baik & $8(3,3 \%)$ & 232 & 240 & & & $(2,63-11,15)$ \\
\hline \multirow{2}{*}{ Sikap } & Negatif & $46(24,5 \%)$ & 142 & 188 & \multirow[t]{2}{*}{45,74} & \multirow[t]{2}{*}{0,000} & 4,92 \\
\hline & Netral positif & $18(5,0 \%)$ & 344 & 362 & & & $(2,94-8,24)$ \\
\hline
\end{tabular}

sesuai tersebut sebagian besar terkait aspek gizi selama hamil/bersalin/nifas dan menyusui $(31,32 \%)$ dan aspek kepercayaan ketika hamil $(29,52 \%)$. Selanjutnya, pernyataan kebiasaan yang dipercayai dalam keseharian responden yang berhubungan dengan kesehatan bayi dan anak balita didapatkan bahwa yang memiliki kepercayaan tidak sesuai dengan nilai-nilai kesehatan sebesar $23,62 \%$. Kepercayaan yang keliru tersebut sebagian besar terkait aspek gizi pada bayi dan balita atau tidak mendukung air susu ibu (ASI) eksklusif $(42,62 \%)$ dan aspek kepercayaan terhadap penanganan kesehatan pada bayi dan anak balita $(27,87 \%)$.

\section{Faktor Pemungkin (Enabling) yang Berhubungan dengan Pelayanan Kesehatan Ibu dan Anak}

Secara umum, jumlah bidan yang merupakan tenaga kesehatan utama dalam pelayanan KIA di Provinsi Riau sudah memadai. Jumlah lulusan pendidikan minimal diploma 3 (D3) kebidanan sudah memenuhi demand bidan di Provinsi Riau. Namun, berdasarkan rasio tenaga bidan dan jumlah penduduk di Provinsi Riau masih belum mencukupi (37 per 100.000 penduduk). Distribusi tenaga bidan di Provinsi Riau masih belum merata, seperti terlihat dari beberapa desa/kelurahan belum ada tenaga bidan, terutama pada kategori desa sangat terpencil. Beberapa desa justru berlebih tenaga bidan, tetapi di beberapa desa jumlah tersebut tidak sesuai dengan cakupan wilayah kerja.

Berdasarkan kualitas ketenagaan pemberi pelayanan KIA, sebagian besar informan mengatakan berdasarkan jenjang pendidikan cukup ideal, sebagian besar bidan minimal berijazah D3 kebidanan. Namun, dari pendidikan-pelatihan untuk peningkatan kompetensi (asuhan persalinan normal, APN; manajemen terpadu bayi muda, MTBM serta penatalaksanaan asfiksia neonatorum) masih kurang. Beberapa puskesmas sudah ada yang mengikuti, tetapi tidak terdistribusi merata ke semua bidan (rata-rata yang sudah mengikuti pelatihan kurang dari $50 \%$ ). Begitu juga terhadap jenis pelatihan yang seharusnya diikuti. Selain tenaga bidan, tenaga pendukung pelayanan KIA lainnya seperti ahli gizi juga masih belum memadai. Tidak semua puskesmas memiliki ahli gizi (minimal pendidikan D3 gizi).

\section{Ketersediaan dan Ketercukupan Sarana Pendukung Pelayanan Kesehatan Ibu dan Anak}

Sebagian besar informan menyatakan aspek sarana pendukung pelayanan KIA pada kategori belum memadai. Beberapa hal yang belum memadai adalah peralatan pendukung pelayanan KIA (sarana laboratorium, sterilisasi alat, dan lain-lain). Kekurangan sarana ini terutama untuk daerah yang jauh, di puskesmas pembantu (pustu) maupun pondok bersalin desa (polindes). Banyak hal yang menyebabkan sarana ini masih kurang, antara lain keterbatasan dana karena ada pengembangan atau penambahan puskesmas baru. Kendala lain adalah fasilitas yang belum termanfaatkan. Hal tersebut antara lain disebabkan oleh tidak ada pelatihan pengoperasian alat, tidak ada tenaga teknisi/analis yang kompeten atau tidak tersedia sarana pendukung pengoperasian alat tersebut, seperti daya 
listrik.

Faktor Pendorong (Reinforcing) yang Berhubungan dengan Pelayanan Kesehatan Ibu dan Anak

Kebijakan yang menjadi acuan dalam pelayanan KIA secara umum adalah mengimplementasikan kebijakan nasional terkait pelayanan KIA. Sasaran yang dicapai adalah berdasarkan standar pelayanan minimal bidang kesehatan (SPM BK) Kementerian Kesehatan Republik Indonesia. Acuan operasional pelaksanaan di daerah adalah surat keputusan bupati/walikota terkait SPM yang sudah ada. Namun untuk hal-hal teknis lain, seperti pengaturan kompetensi tenaga kesehatan belum diatur melalui kebijakan daerah seperti peraturan daerah (peraturan gubernur dan bupati/walikota).

Aspek prasarana pendukung pelayanan KIA sebagian besar berada pada kategori memadai. Beberapa hal yang dianggap sudah baik adalah kebijakan yang jelas terhadap pelayanan KIA, khusus untuk masyarakat miskin tersedia panduan kegiatan (dalam bentuk buku atau modul). Pada beberapa puskesmas, walaupun pedoman sudah ada terkadang jumlahnya belum mencukupi.

Kecukupan dana untuk mendukung pelayanan KIA ada yang merasa sudah memadai, namun ada juga yang mengatakan belum memadai. Dana untuk kegiatan rutin/kegiatan tugas pokok dan fungsi dari tenaga kesehatan seperti antenatal care (ANC) di pelayanan primer dianggap cukup memadai. Beberapa daerah terjadi penurunan anggaran untuk pelayanan KIA. Untuk kegiatan tertentu, anggaran tersebut tidak tersedia, terutama untuk pengembangan program dan peningkatan kualitas tenaga kesehatan. Pelayanan KIA untuk masyarakat sudah tersedia dana yang memadai, mengingat kebijakan pelayanan gratis terutama untuk masyarakat miskin.

Beberapa kegiatan dalam pelayanan KIA juga melibatkan lintas sektoral seperti pembinaan upaya kesehatan berbasis masyarakat (UKBM) dengan pemberdayaan dan kesejahteraan keluarga (PKK) (pos pelayanan terpadu, posyandu; bina keluarga balita, BKB; tanaman obat keluarga, toga; dan lain-lain), dengan Dinas Pendidikan Pemuda dan Olahraga (unit kesehatan sekolah, UKS; pembinaan perilaku hidup bersih dan sehat, PHBS; serta bulan imunisasi anak sekolah) serta dengan Dinas Pertanian dan Ketahanan Pangan (peningkatan gizi masyarakat). Kegiatan yang dilakukan secara lintas sektoral secara umum tidak bermasalah. Namun, jumlah kegiatan lintas sektoral masih banyak yang belum terealisasi sehingga kegiatan ini hanya dilakukan oleh dinas kesehatan sehingga tidak mencapai target. Berbagai kendala yang masih dihadapi antara lain pola koordinasi kegiatan belum dirumuskan dan tidak diikat dengan memorandum of understanding (MOU) yang jelas.

Leading sector KB di kabupaten/kota adalah Satuan Kerja Pemerintah Daerah (SKPD) Badan Pemberdayaan Perempuan dan Keluarga Berencana (BPP-KB). Sedangkan untuk urusan kesehatan dilakukan oleh Seksi KIA. Bentuk kerja sama kegiatan KB antara leading sector tersebut saling berkoordinasi untuk meningkatkan pelayanan KB. SKPD kesehatan lebih ke arah meningkatkan cakupan peserta KB aktif dan peserta KB. Tugas utama SKPD BPP-KB menyediakan alat kontrasepsi, meningkatkan akseptor baru serta meningkakan kualitas tenaga penyuluh dan teknis dalam pelayanan KB.

Implementasi dan koordinasi antarsektor dianggap masih belum optimal, terbukti sering terjadi ketidaksinkronan data dari masing-masing SKPD. Selain itu, koordinasi laporan kegiatan juga tidak berlangsung secara optimal. Kegiatan yang dilakukan oleh SKPD tertentu tidak dikoordinaksikan secara institusi. Dampaknya, banyak kegiatan yang sudah direncanakan tidak terlaksana secara optimal sehingga terjadi kesenjangan antara jumlah akseptor dengan ketersediaan alat kontrasepsi. Sering terjadi ketidaktersediaan/ketidaksesuaian alat kontrasepsi dengan kebutuhan di lapangan. Beberapa kegiatan yang dilaksanakan terpadu seperti KB kesehatan manunggal juga sering tidak terjadi secara optimal dan tidak didukung oleh MOU/ikatan kerja sama yang jelas. Kondisi seperti ini berdampak pada menurunnya peserta KB aktif di beberapa daerah.

\section{Pembahasan}

Faktor Predisposisi Permasalahan Kesehatan Ibu dan Anak

Faktor-faktor yang diketahui berhubungan bermakna secara statistik dengan praktik responden terkait kesehatan maternal adalah cara pembayaran kesehatan, aksesabilitas terhadap fasilitas kesehatan, pengaruh orang yang memutuskan dalam upaya pencarian pelayanan kesehatan, pengetahuan responden tentang kesehatan ibu serta sikap ibu terhadap pelayanan kesehatan selama hamil, bersalin, dan nifas. Hasil penelitian ini tidak jauh berbeda dengan penelitian Marpaung, ${ }^{3}$ dan Rahman, ${ }^{4}$ salah satu faktor jumlah anak tidak berhubungan dengan praktik yang buruk. Hasil ini mengindikasikan program pemerintah menjamin pelayanan kesehatan terutama untuk masyarakat miskin dan kebijakan pelayanan gratis akan berdampak pada perbaikan praktik masyarakat dalam pelayanan kesehatan. Hal itu berarti bahwa berapa pun jumlah anggota keluarga dan pendapatan keluarga, jika mereka dijamin mendapatkan layanan kesehatan, praktik mereka akan baik.

Variabel yang berhubungan dengan kesehatan bayi dan anak adalah usia pernikahan, jumlah anak, pendapatan keluarga, cara pembayaran kesehatan, aksesabilitas terhadap fasilitas kesehatan, pengaruh 
orang yang memutuskan dalam upaya pencarian pelayanan kesehatan, pengetahuan serta sikap responden terhadap pelayanan kesehatan bayi dan anak. Variabel pengaruh orang yang memutuskan dalam upaya pencarian pelayanan kesehatan dan pengetahuan responden merupakan variabel dengan nilai PR terbesar yang menentukan praktik kesehatan bayi dan anak. Faktor sosial ekonomi berhubungan dengan praktik masyarakat. Hasil analisis multivariat menunjukkan 3 variabel bebas secara bersama berpengaruh bermakna terhadap praktik buruk kesehatan ibu maternal serta kesehatan bayi dan anak.

Sikap merupakan variabel yang berpengaruh kuat terhadap praktik responden yang buruk dalam pelayanan KIA. Penelitian Setyaningsih, ${ }^{5}$ membuktikan bahwa sikap ibu balita secara bermakna berhubungan terhadap praktik ibu balita dalam pencegahan anemia balita $(\mathrm{p}=0,028)$. Juliwanto, ${ }^{6}$ juga membuktikan bahwa sikap seseorang yang negatif terhadap pelayanan kesehatan membuat seseorang 5 kali lebih besar memilih tenaga nonkesehatan dalam pertolongan persalinannya. Sikap merupakan variabel dominan pembentuk perilaku. Sikap tidak mudah untuk dibentuk, apalagi sikap yang positif terhadap suatu objek. Azwar, ${ }^{7}$ menyatakan bahwa banyak faktor yang mempengaruhi pembentukan sikap seseorang terutama hubungannya dengan objek tertentu dalam berinteraksi sosial, dimana terjadi hubungan saling mempengaruhi perilaku individu tersebut sebagai anggota masyarakat. Individu bereaksi membentuk sikap tertentu terhadap objek psikologis yang dihadapinya. Kurangnya stimulasi positif menimbulkan hanya sebagian kecil orang memiliki pengetahuan tentang objek tertentu. Selanjutnya, kurangnya rangsangan positif juga akan berpengaruh terhadap bertahannya kondisi sikap yang netral, bahkan dapat menjadi sikap negatif yang berujung tidak diterapkannya dalam praktik yang diinginkan.

Orang yang memutuskan pemilihan pelayanan kesehatan dalam keluarga merupakan variabel yang berpengaruh kuat terhadap praktik pelayanan kesehatan maternal, bayi, dan anak. Pola pengambilan keputusan dalam keluarga akan menentukan praktik pelayanan kesehatan termasuk pelayanan KIA. Pengaruh orang lain, apakah itu orang tua/mertua dan kerabat keluarga lain, membuat keputusan yang akan diambil sering menjadi terlambat, terkadang membingungkan karena banyaknya pilihan. Hal tersebut akan menyebabkan praktik keluarga yang buruk. Suami dan istri harus mempunyai otonomi penuh dalam keputusan praktik KIA tanpa mengabaikan masukan dari orang lain karena jika posisi tersebut kuat keputusan dapat terealisasi dengan cepat. Oleh karena itu, suami/istri harus berpengetahuan benar tentang praktik pelayanan KIA, misalnya dalam perawatan kehamilan dan persalinan yang aman dan sehat. ${ }^{8}$ Penelitian Danfort, Kruk, Rockers, Mbaruku, dan Galea, ${ }^{9}$ membuktikan bagaimana pentingnya peran suami dan istri dalam pengambilan keputusan terkait proses persalinan dan menentukan tempat persalinan.

Penelitian ini membuktikan bahwa pengetahuan seseorang berhubungan dengan praktik pelayanan KIA. Hasil ini mendukung penelitian-penelitian lain yang telah membuktikan bahwa pengetahuan sebagai salah satu faktor dominan pembentuk perilaku seseorang. Penelitian Setyaningsih, ${ }^{5}$ membuktikan bahwa pengetahuan secara bermakna berhubungan terhadap praktik ibu balita dalam pencegahan anemia gizi besi balita $(\mathrm{p}=0,003)$. Menurut Notoatmodjo, ${ }^{10}$ pengetahuan yang belum ideal merupakan salah satu penyebab permasalahan kesehatan yang terjadi di masyarakat. Seseorang yang belum berpengetahuan baik akan sulit melakukan perubahan perilaku ke arah yang lebih baik atau menerima perilaku baru yang lebih baik. Pengetahuan baik merupakan salah satu modal awal untuk praktik yang baik, hingga akhirnya terjadi penurunan kasus/masalah kesehatan atau akan meningkatkan indikator pelayanan kesehatan di masyarakat. ${ }^{10}$

Penelitian ini membuktikan bahwa variabel aksesabilitas pelayanan kesehatan menentukan praktik kesehatan maternal. Secara umum, diketahui bahwa aspek kemudahan akses fasilitas kesehatan tetapi praktik yang buruk banyak ditemukan pada kelompok yang mengatakan aksesabilitas pelayanan sulit dijangkau. Apabila aksesabilitas pelayanan kesehatan buruk maka masyarakat tidak mendapatkan informasi dan pelayanan yang cukup dari petugas kesehatan yang bermuara pada praktik kesehatan yang buruk. Khusus untuk pelayanan kesehatan bayi dan anak, variabel cara pembayaran sangat menentukan praktik seseorang terkait kesehatan bayi dan anak. Menurut Fuadi, ${ }^{11}$ pembayaran kesehatan secara mandiri menyebabkan beban ekonomi yang berat bagi keluarga karena biaya kesehatan memang mahal sehingga mereka sering tidak terakses pelayanan kesehatan.

Masih banyak kepercayaan masyarakat yang belum sesuai dengan nilai-nilai kesehatan. Juliwanto, ${ }^{6}$ membuktikan bahwa ada budaya yang tidak mendukung nilai kesehatan menjadi faktor penentu praktik pelayanan kesehatan masyarakat yang buruk, misalnya dalam memilih tenaga penolong persalinan. Pemilihan tenaga nonkesehatan dalam pertolongan persalinan 24 kali lebih besar pada orang dengan budaya yang tidak mendukung.

\section{Faktor Pemungkin (Enabling) yang Berhubungan dengan Pelayanan Kesehatan Ibu dan Anak}

Secara umum, ketersediaan tenaga bidan di Provinsi Riau relatif sudah memadai, tetapi terdistribusi tidak 
merata. Akibatnya, pelayanan komprehensif yang diterima kurang dan pilihan masyarakat terhadap tenaga nonkesehatan meningkat. Penelitian Setyaningsih, ${ }^{5}$ membuktikan bahwa interaksi petugas kesehatan dengan responden secara bermakna berhubungan terhadap praktik ibu balita dalam pencegahan anemia gizi besi balita ( $\mathrm{p}$ $=0,014)$. Berdasarkan aspek kualitas tenaga pelayanan KIA, aspek jenjang pendidikan sudah cukup ideal, tetapi dari aspek pendidikan dan pelatihan untuk meningkatkan kemampuan kompetensi masih belum maksimal. Kesadaran tenaga kesehatan terhadap kualitas harus terus ditingkatkan karena permasalahan kesehatan sering terjadi pada petugas yang kurang kompeten dan kepuasan pengguna jasa juga tidak akan terwujud. Penelitian Sari, 12 membuktikan bahwa kualitas pelayanan berhubungan dengan tingkat pemanfaatan posyandu $(\mathrm{p}=0,001)$, artinya orang tidak akan mewujudkan praktik ideal dalam pelayanan kesehatan jika tidak didukung oleh pelayanan tenaga kesehatan yang kompeten.

Sarana pendukung pelayanan KIA berada pada kategori belum memadai. Banyak penelitian yang membuktikan bahwa keberadaan sarana menentukan kualitas praktik seseorang dalam pelayanan kesehatan serta memicu masalah kesehatan. Penelitian Sari, ${ }^{12}$ membuktikan bahwa ketersediaan sarana berhubungan dengan tingkat pemanfaatan posyandu $(\mathrm{p}=0,001)$. Tidak tersedianya sarana kesehatan membuat orang tidak puas dengan pelayanan yang diterima. Selain itu, petugas kesehatan tidak maksimal dalam memberikan pelayanan kepada masyarakat.

\section{Faktor Pendorong (Reinforcing) yang Berhubungan dengan Pelayanan Kesehatan Ibu dan Anak}

Kecukupan prasarana pendukung pelayanan KIA sangat menetukan permasalahan KIA. Untuk hal-hal teknis terkait pelayanan KIA seperti pengaturan kompetensi tenaga kesehatan belum diatur melalui peraturan daerah. Hal ini berdampak pada acuan yang jelas atau jaminan pemberian pelayanan KIA secara efektif dan efisien. Menurut Asfian, ${ }^{13}$ pedoman kerja merupakan panduan, terutama apabila terdapat pergantian/perubahan karyawan sehingga dapat digunakan untuk menilai. Selanjutnya, Azwar, ${ }^{14}$ mengatakan pedoman kerja mempunyai peranan yang cukup penting karena standar dipakai sebagai bahan bandingan. Untuk memandu para pelaksana program menjaga mutu agar tetap berpedoman pada standar yang telah ditetapkan maka disusun pedoman atau petunjuk pelaksana. ${ }^{14}$ Aspek kecukupan dana pendukung pelayanan KIA belum memadai. Hasil penelitian membuktikan bahwa dana merupakan faktor utama yang berperan dalam mewujudkan pelayanan KIA. Tidak cukupnya dana membuat banyak program KIA yang seharusnya dilaksanakan tidak dapat terwujud atau tidak maksimal dilakukan. Dana merupakan salah satu unsur yang tidak dapat diabaikan. Oleh karena itu, dana merupakan alat yang penting untuk mencapai tujuan. ${ }^{15}$

Secara umum, untuk kegiatan-kegiatan yang sudah dilakukan secara lintas sektoral tidak bermasalah, tetapi kegiatan yang seharusnya dilakukan secara lintas sektoral banyak yang belum terealisasi. Oleh karena itu, kegiatan ini hanya dilakukan oleh dinas kesehatan yang berdampak pencapaian target pelayanan KIA yang rendah. Implementasi dan koordinasi antarsektor program KB belum optimal, terbukti sering terjadi ketidaksinkronan data dari masing-masing SKPD. Selain itu, koordinasi laporan kegiatan tidak berlangsung optimal. Bukti lain adalah bentuk kegiatan yang dilakukan oleh SKPD tertentu tidak dikoordinaksikan secara institusi. Hal ini berdampak pada kegiatan yang direncanakan tidak terlaksana secara optimal. Misalnya, kesenjangan antara jumlah akseptor dengan ketersediaan alat kontrasepsi di lapangan. Beberapa kegiatan yang dilaksanakan terpadu seperti KB kesehatan manunggal di lapangan sering tidak didasari oleh MOU/ikatan kerja sama yang jelas. Kondisi seperti ini berdampak pada menurunnya peserta KB aktif di beberapa daerah (tidak mencapai target).

\section{Kesimpulan}

Faktor-faktor yang berhubungan dengan pelayanan KIA termasuk faktor predisposisi, yaitu sikap responden, praktik responden yang buruk 8 kali lebih banyak pada responden yang memiliki sikap negatif daripada yang memiliki sikap positif. Pengaruh orang yang memutuskan pemilihan pelayanan kesehatan dalam keluarga merupakan variabel yang berpengaruh kuat terhadap praktik responden terkait pelayanan kesehatan bayi dan anak. praktik yang buruk 6 kali lebih banyak pada responden yang pengambilan keputusannya dilakukan suami-istri dan melibatkan orang lain daripada hanya suami-istri. Pengetahuan responden terkait pelayanan KIA dan aksesabilitas terhadap pelayanan kesehatan juga menentukan praktik seseorang terkait kesehatan maternal dan pelayanan kesehatan bayi dan anak. Cara pembayaran juga sangat menentukan praktik seseorang terkait kesehatan bayi dan anak serta kepercayaan masyarakat yang belum sesuai dengan nilai-nilai kesehatan, terutama terhadap aspek KIA. Faktor pemungkin yang berhubungan dengan pelayanan KIA, antara lain distribusi tenaga kesehatan masih belum merata, kualitas ketenagaan pemberi pelayanan KIA masih belum optimal dan sarana pendukung pelayanan belum memadai. Faktor pendorong yang berhubungan, antara lain belum adanya kebijakan daerah sebagai acuan dalam pelayanan KIA, dana untuk mendukung pelayanan KIA belum memadai, kuantitas kegiatan yang seharusnya 
dilakukan secara lintas sektoral masih banyak yang belum terealisasi serta koordinasi antarsektor untuk program KB masih belum optimal.

\section{Saran}

Meningkatkan proporsi anggaran dan jumlah kegiatan promosi kesehatan kepada masyarakat, difokuskan untuk mengubah perilaku, mengupayakan pola kemandirian keluarga dalam menentukan pilihan dalam pelayanan kesehatan (meminimalisasi hambatan sosiokultural terhadap pelayanan KIA). Meningkatkan upaya menambah kompetensi tenaga kesehatan, khususnya dalam pelayanan KIA (peningkatan anggaran untuk peningkatan kualitas sumber daya manusia), terus dilakukan upaya optimalisasi pendistribusian tenaga kesehatan serta pemantauan/supervisi rutin untuk menjamin keberadaan tenaga kesehatan di lapangan. Mempertahankan dan meningkatkan upaya advokasi dalam mengupayakan dikeluarkannya kebijakan lokal yang akan mempermudah pelayanan KIA kepada masyarakat, meningkatkan anggaran untuk pelayanan KIA, peningkatan realisasi kegiatan yang dilakukan secara lintas sektoral serta merumuskan pola koordinasi kegiatan yang lebih baik dan diikat melalui MOU yang jelas. Khusus koordinasi antarsektor terutama untuk pelayanan $\mathrm{KB}$, perlu dioptimalkan (dikaji ulang dan dicari solusi yang tepat).

\section{Daftar Pustaka}

1. Kementerian Kesehatan Republik Indonesia. Ibu selamat, bayi sehat, suami siaga. Jakarta: Kementerian Kesehatan Republik Indonesia; 2009 [diakses tanggal 3 Februari 2010]. Diunduh dari: http://www.depkes.go.id/index.php/berita/press-release/790-ibu-selamat-bayi-sehat-suami-siaga.html.

2. Dinas Kesehatan Provinsi Riau. Profil kesehatan Provinsi Riau tahun 2007. Riau: Dinas Kesehatan Provinsi Riau; 2007.

3. Marpaung FV. Pengaruh faktor predisposisi, pendukung, dan pendorong terhadap pemanfaatan penolong persalinan oleh ibu di wilayah kerja
Puskesmas Butar Kecamatan Pagaran Kabupaten Tapanuli Utara tahun 2010 [skripsi]. Medan: Fakultas Kesehatan Masyarakat Universitas Sumatera Utara; 2010.

4. Rahman KMM. Determinants of maternal health care ytilization in Bangladesh. Research Journal of Applied Science. 2009; 4 (3): 113-9.

5. Setyaningsih S. Pengaruh interaksi, pengetahuan, dan sikap terhadap praktik ibu dalam pencegahan anemia gizi besi balita di Kota Pekalongan tahun 2008 [tesis]. Semarang: Universitas Diponegoro; 2008.

6. Juliwanto. Faktor-faktor yang mempengaruhi keputusan memilih penolong persalinan pada ibu hamil di Kecamatan Babul Rahmah Kabupaten Aceh Tenggara tahun 2008 [tesis]. Medan: Universitas Sumatera Utara; 2009.

7. Azwar S. Sikap manusia, teori, dan pengukurannya. Yogyakarta: Pustaka Pelajar Offset; 2000.

8. Musadad A, Rachmalina, Rahajeng E. Pengambilan keputusan dalam pertolongan persalinan di Provinsi Nusa Tenggara Timur. 2003 [diakses tanggal 2 November 2009]. Diunduh dari: http://www.ekologi.litbang.depkes.go.id/data/vol\%202/Anwar2_1.pdf.

9. Danfort EJ, Kruk ME, Rockers PC, Mbaruku G, Galea S. Household decision-making about delivery in health facilities: evidence from Tanzania. International Centre For Diarrhoeal Disease Research Bangladesh. J Health Popul Nutr. 2009; 27 (5): 696-703.

10. Notoatmodjo S. Promosi kesehatan: teori dan aplikasi. Jakarta: PT Rineka Cipta; 2005.

11. Fuadi A. Tinjauan yuridis pelaksanaan jaminan kesehatan masyarakat di Rumah Sakit Umum Daerah dr. Raden Soedjati Kabupaten Grobogan [skripsi]. Surakarta: Universitas Muhamadiyah; 2009.

12. Sari RW. Hubungan karakteristik ibu hamil, ketersediaan sarana, dan kualitas pelayanan dengan tingkat pemanfaatan posyandu [skripsi]. 2007.

13. Asfian. Analisis pemanfaatan pedoman kerja bidan dalam pengelolaan program KIA KB di Puskesmas Kota Pontianak [tesis]. Semarang: Universitas Diponegoro; 2008.

14. Azwar A. Menjaga mutu pelayanan kesehatan. Jakarta: Pustaka Sinar Harapan; 1999.

15. Siahaan. Analisis pelaksanaan pemberdayaan masyarakat. 2010 (diakses tanggal 14 Desember 2010). Diunduh dari: http://reposi- 